\title{
Planning and Record Keeping of Educational Work Done by Professional and Teaching Staff While Implementing Distance Learning Training Programs
}

\author{
O.V. Sviridenko ${ }^{1}$, V.Y. Bauer ${ }^{1}$, Y.A. Baluyeva ${ }^{1}$, E.V. Komerzan ${ }^{1}$

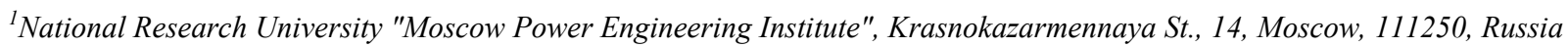 \\ *Corresponding author E-mail: sviridenko.o.v@mail.ru
}

\begin{abstract}
Organization of the educational process includes planning teachers' work carried out while implementing BPEP in distance learning form. An important objective of this stage is to identify certain types of teachers' work that differ from the classroom and their rationing. At the Russian universities, the planning system has been used for more than half a century, however, the emergence of new teaching technologies requires making significant changes to it. The article describes the educational work planning process done by the professional and teaching staff of "NRU" MPEI" carried out while implementing educational programs with distant education technologies; certain types of teachers' work were found out and standard time to accomplish them was set.
\end{abstract}

Keywords: Educational Process; Distance Learning; Distance Education Technologies; Planning Teacher's Educational Work; Standartization Of Teacher's Educational Work

\section{Introduction}

The result of the information revolution is the society's transition to a qualitatively new level of development. Nowadays, information processes operation has become one of the most important components of human society and life. In this regard, it is reasonable to believe that the objectives, content and technology in the current educational practice should be focused on ensuring timely and adequate preparation of students for modern conditions.

Today distance technologies are not rare, however generally accepted practice of planning and record keeping of teaching staff's work has not been worked out yet.

Considering the issue of organizing the work of teachers engaged in the educational process using distance technologies, it is necessary to take into account the specifics of the new qualification requirements and draw on the traditional methods of accounting the load applied in Russia.

\section{Types of Teachers' Work in "Nru" Mpei" Carried out While Implementing Distance Educational Programs}

In "NRU" MPEI" organization of the educational process with the use of distance technologies is carried out by the Institute of Distance and additional education in accordance with the curriculum of basic professional educational programs (BPEP). The educational process is based on the use of modern information and telecommunication technologies, Internet educational resources and provides efficient use of the developed content for distance learning while systematically teaching classes in accordance with the calendar, which is an integral part of the curriculum and establishes institutional requirements for the modern university lecturer (Fig. 1).

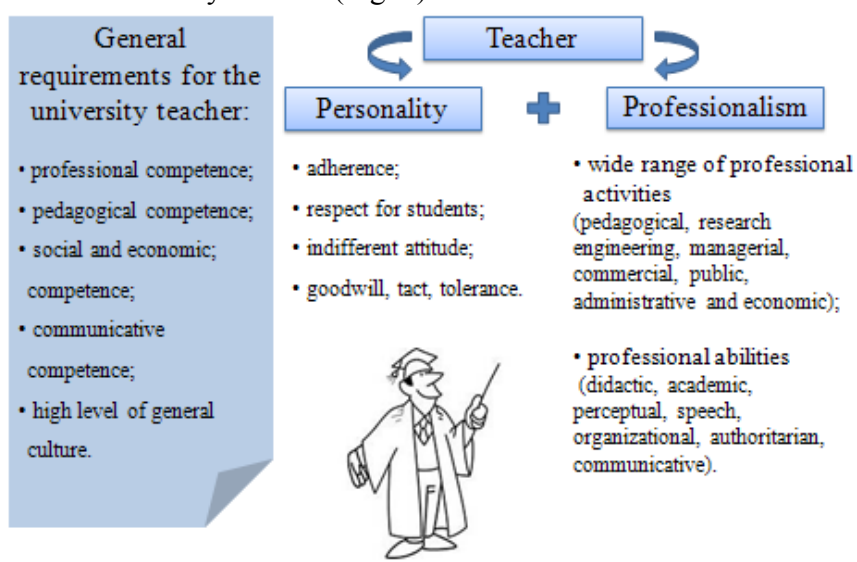

Fig. 1: Teacher: modern institutional requirements

Organization of the educational process includes planning teachers' work carried out while implementing BPEP in distance learning form. An important objective of this stage is to identify certain types of teachers' work that differ from the classroom and their rationing.

The following types of professional and teaching staff work are performed with the use of distance learning technologies (DLT):

The development of an online course, including all educational, methodical and certification materials.

Reading lectures, supervising practical work using DLT.

Processing test results of the final or interim certification.

Marking the tests.

Supervising course works and projects.

Supervising students' experimental and scientific research work. 
Supervising internship, practical training and pre-graduation practice.

Supervising students' qualifying projects.

Current trends in the organization of the educational process create a range of requirements for the competence of modern teachers (Fig. 2).

The teacher should possess a variety of educational technologies, have a personal style in work, have a high level of professional culture and at the same time be understandable to the youth. The teacher must have the skills of scientific work, be sociable and have a high level of knowledge of information technologies.

Increasing the requirements for the teacher becomes one of the paradigms of the development of the rationing system, used to assess the work of a modern university teacher.

\section{Standartization of Professional and Teaching Staff Work Carried out with The Use of DLT}

In order to take into account the specifics of the work of the teaching staff in the implementation of educational programs in 2018, the IDDO staff developed time standards regulating the process of implementing the selected types of academic work of the faculty in a distance form. Standardization was performed to plan teacher's workload for the following year, determine the number of teaching staff and execute payrolls.

The course content with the use of DLT includes the supervision of individual study of educational material schedule of various events, lecture material, practical training sessions (field, creative tasks, problematic issues, case study, etc.), examples of assignments, test materials, tasks for self-control, additional electronic teaching materials (handbooks, dictionaries, etc.), reading lists, including Internet links. The use of modern information technologies enables the development of video lectures, interactive multimedia lectures, audio lectures, which contributes to the effective learning of educational material $[1,2,3]$.

Rationing is based on the analysis of the experience of financial relations with the developers of training courses using the inverse method of calculating economic indicators. The financial expectations of the MEI teachers and the market-established cost of remuneration were taken as the basis for the standardization. Then, the average cost of the unit of time needed to work and the numerical index of the load were calculated.

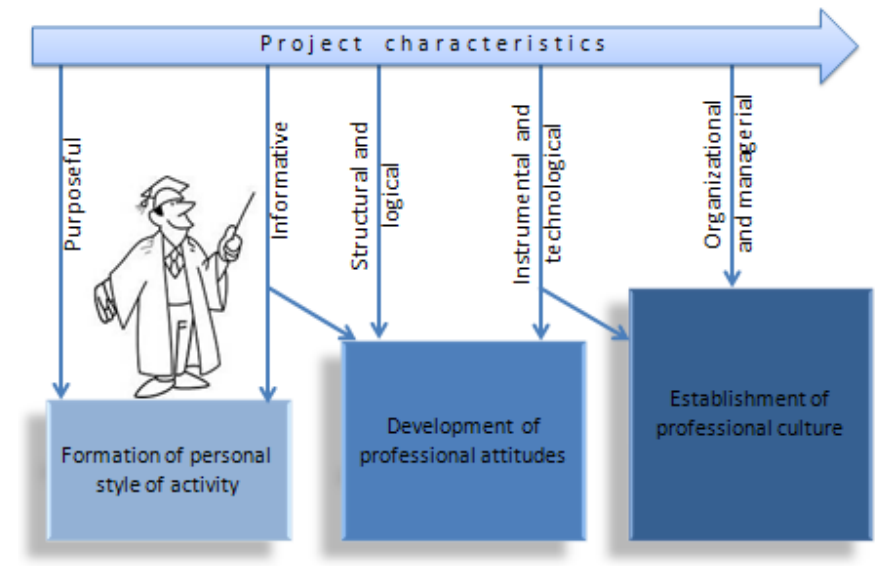

Fig. 2: The model of the teacher taking into account the design characteristics

Creating a new online course of a discipline including all the necessary teaching and assessment materials takes 10-40 needed to work and the numerical index of the load were calculated hours depending on the course complexity. To conduct a class that corresponds to 1 hour of a traditional lecture or seminar using DOT, it takes time to work with the group and the time for individual contact work, this is divided approximately in equal proportions.

The use of distance learning is based on students' independent cognitive activity while studying educational material. Therefore, one of the most important tasks is to control the quality of learning. Also, it is becoming more important to control the process theoretical knowledge formation, practical skills and abilities; it is particularly significant for distance learning system because of the lack of direct contact between teachers and students. Special claims are laid to the quality control system while using distance technologies in education due to the fact that it performs not only the control function, but also carries out organizational, educational and training ones.

To ensure the effectiveness of the control and assessment system, the stages and the assessment forms are determined; the means of implementation are chosen. Continuous assessment, inter-term and final tests are provided. These forms of control are realized in the form of quizzes, tests, exams, defending course works and protects, final qualification works.

Using information technology allows to do tests which are simple universal means of examination. Since the testing process is automated the labor costs of tests making, organizing the process and tests marking are reduced. This approach helps to conduct a survey quickly and efficiently as often as it is required, providing a good feedback. Based on the features of the automated testing process it takes 0.3 hours to mark one test, which also takes into consideration the labor costs for processing test materials and the specifics of the groups.

An important type of teacher's educational work is to supervise students' course works and projects aimed at a deeper study of the discipline foundations, understanding of their practical importance, the development of the ability to analyze theoretical problems. Supervising course works and projects includes concurrence of themes, consultation, monitoring and assessment of the work done. The standard time for 1 work is 1,5 hours. Course projects are a more complex kind of student's academic work which includes graphic and calculation parts. This type of work may contain a material part in the form of models, an economic part reflecting the analysis of the effect which can be obtained after the project realization. The complexity of this type of study determines the increase in the standard time up to 2 hours on the leadership of one project per student. Advice on WRC is not different from working with students in the traditional form and is 15 hours per 1 bachelor or 25 hours for 1 master.

At the present stage of higher school development it is important to organize and develop students' scientific and research work, which is an effective form of training highly qualified specialists $[4,5,6]$. In accordance with the new standards, students doing bachelor's and master's degrees have to be able to do research. While supervising students' research work the teacher organizes his activities in such a way as to expand the knowledge of the theoretical foundations of disciplines, to develop practical skills of independent research, creative and analytical thinking, literate presentation of the research results, their reasoned justification. Due to this organization of research work, students master different types of creative activities that will allow them to introduce the elements of scientific approach in their professional activities, to develop a commitment to cognitive activity. In most cases, the subjects of research works are linked to the main scientific directions of the department qualifying the student. It is possible to carry out work in collaboration with other departments, thus strengthening interdepartmental and inter-faculty communication, creating the conditions for continued cooperation. Attracting students to the department's scientific work is an effective way of interest formation in this area.

Supervising research work means choosing the subject by the teacher, its agreement with students, counseling, monitoring and assessment. This process involves the scientific supervisor which advises the students in a particular scientific field and the tutor who is in charge of the execution and assessment of the report on 
the work done. The standard time of supervising one work is 2 hours a term. The standard time of marking one report by a tutor is 0.3 hours a term.

Experimental research is a form of students' scientific work. Its main task is to develop their abilities to justify the results of experiments, prove them experimentally and formulate conclusions. While carrying out experimental work the level of learning theoretical material significantly increases. The standard time of consulting one student on the research work is 1 hour a term. The standard time of marking one report by a tutor is 0.3 hours a term.

In accordance with BPEP an important part of the learning process based on the use of DLT is practical training. Targets, tasks, work content fully comply with the federal state educational standards in the areas of training. The periods of all kinds of practical sessions are approved in the calendar of the educational process. There are the following types of practices:

Training practice aimed at obtaining primary professional skills. Field practice which contributes to the acquisition of professional skills and experience of professional activity.

Work pre-graduation practice focused on the preparation of materials for writing the final qualification work, mastering the knowledge and skills acquired in the course of learning, opportunities of independent work in a particular production.

The organizations serving as bases for field practice are chosen in spite of their ownership forms and their activity corresponds to professional competencies acquired during BPEP. The practice organization is carried out on the basis of the contracts with the enterprises. Supervisors are assigned to control the student during the practice period, one of them is a member of professional and teaching staff of "NRU" MPEI", the other is a member of the enterprise's staff.

Practice supervision involves drafting work schedule, group counseling of students, monitoring the practical training process, marking the final reports on the work performed. A differentiated credit is a form of assessment of all types of practice, which is carried out in the form of defense of student reports. This process includes:

Student's placement of the practice report in the personal account of distance learning system "Prometei".

Marking the report by the practice supervisor.

Formulation of questions on the implementation of tasks and placing them in the private account of the student.

Students' answers to the questions.

The evaluation of the answers received and grading at the end of the internship.

The main forms of distance learning in this case are consultation and supervision. The standard time of group consulting is 2 hours for 1 supervisor. The standard time of marking one student's report on the training and field practice to acquire primary professional skills is 0.3 hours. The scheduled time to mark the report on the pre-graduation field practice is more, because its content determined by the subject of the final qualification work may include the research results, testing, solving creative problems in the major discipline, the development of technological processes, etc. The standard time of marking one student's report on the pre-graduation practice is 1 hour.

The supervision of general professional educational programs based on the use of distance learning technologies is carried out by the managers competent in vocational counselling, the organization of the educational process, assessing the quality of education, promoting employment and professional development of graduates. The experience and qualifications of BPEP managers help to perform all the functions necessary for the management of the program, which is a complex scientific and practical task, requiring the analysis of existing technologies and the development of new ones. The BPEP manager coordinates the work on providing training and methodological support of educational process, assessment methods, monitors the students' progress, increases the effectiveness of the educational process, optimizing the workload of teachers and students, etc. Based on the complexity of work types, the BPEP manager is scheduled with 2 hours for a graduate student and 1 hour for an undergraduate.

\section{Conclusion}

As a result of the work performed, standard time is scheduled for all kinds of training activities carried out by the teaching staff with the DLT. The results are shown in Table 1

Table 1: Standard time of the professional and teaching staff work load carried out in the course of educational activities with the use of distance learning technologies

\begin{tabular}{|c|c|c|}
\hline No & $\begin{array}{l}\text { Types of the teacher's educational } \\
\text { work carried out with the use of DLT }\end{array}$ & Standard time in hours \\
\hline 1 & $\begin{array}{l}\text { Delivering lectures, supervising practical } \\
\text { work }\end{array}$ & $\begin{array}{l}0.5 \text { hours in one } \\
\text { academic hour }\end{array}$ \\
\hline 2 & $\begin{array}{l}\text { Processing of test results during } \\
\text { qualifying evaluation, mid-term tests, } \\
\text { credits, exams, marking tests using DLT }\end{array}$ & $\begin{array}{l}0.3 \text { hours to mark one } \\
\text { test }\end{array}$ \\
\hline 3 & Supervising course projects & $\begin{array}{l}2 \text { hours for counseling } \\
\text { and marking } 1 \text { work }\end{array}$ \\
\hline 4 & Supervising term papers & $\begin{array}{l}1.5 \text { hours for counseling } \\
\text { and testing one work }\end{array}$ \\
\hline 5 & $\begin{array}{l}\text { Supervising experimental research work } \\
\text { (ERW) and scientific research work } \\
\text { (SRW) }\end{array}$ & $\begin{array}{l}\text { For an ER scientific } \\
\text { supervisor: } \\
1 \text { hour for counseling } 1 \\
\text { student a term } \\
\text { For a scientific research } \\
\text { supervisor: } \\
2 \text { hours for counseling } 1 \\
\text { student a term } \\
\text { For a tutor: } \\
0.3 \text { hours for marking } \\
\text { one report }\end{array}$ \\
\hline 6 & Supervising training and field practice & $\begin{array}{l}2 \text { hours for group } \\
\text { counseling } \\
0.3 \text { hours for marking } \\
\text { one report }\end{array}$ \\
\hline 7 & Supervising pre-graduation practice & $\begin{array}{l}2 \text { hours for group } \\
\text { counseling } \\
1 \text { hour for checking one } \\
\text { report }\end{array}$ \\
\hline 8 & $\begin{array}{l}\text { Online course development, including all } \\
\text { educational, methodical and certification } \\
\text { materials }\end{array}$ & $\begin{array}{l}10-40 \text { hours for the } \\
\text { development of } 1 \text { online } \\
\text { course }\end{array}$ \\
\hline 9 & Supervising educational program & $\begin{array}{l}\text { For a graduate student: } \\
2 \text { hours for a student a } \\
\text { year } \\
\text { For undergraduate } \\
\text { students: } \\
1 \text { hour for one student a } \\
\text { year }\end{array}$ \\
\hline
\end{tabular}

Thus, this work defined the specific character of the educational process with the use of DLT, pointed out the types of educational work specific for distance learning, set the standard time for the accomplishment. It was determined that when using distant technologies in educational process a general reduction of the teachers' workload is evident. This effect is observed mainly due to the use of information technologies, didactic functions redistribution between different forms of educational activity, reduction the number of lectures and practical classes.

\section{References}

[1] Federal law from 12.29.2012 № 273-Federal law (edited on 05.01.2017, changed on 07.05.2017) "Education in the Russian Federation".

http://pravo.gov.ru/proxy/ips/?docbody $=\&$ firstDoc $=1 \&$ lastDoc $=1 \&$ $\mathrm{nd}=102162745$ 
[2] Letter of the Ministry of Education of the Russian Federation № 14-55-784 in 15 of 26.06 .2003 https://gkrfkod.ru/zakonodatelstvo/pismo-minobrazovanija-rf-ot26062003-n-14-55-784in15/

[3] Order of the Ministry of Healthcare and Social Development of the Russian Federation of August 26, 2010 № 761n Moscow "On Approval of the Unified Qualification Reference Book for the Positions of Executives, Specialists and Employees, section "Qualification Characteristics of the Positions of Educators". https://rg.ru/2010/10/20/teacher-dok.html

[4] T.N. Yamshchikova, T.A. Zhuravleva, I.V. Skoblyakova, To a question about the rules of time training and other load high school teacher in Russian universities, Management and business administration, 4, (2017), 170-184.

[5] M.I. Averyanova, Peculiarities of determining the duration of working hours of pedagogical workers of general education organizations, Russian Yearbook of Labor Law, 9, (2014), 426-437.

[6] O.V. Grigorash, On the need to change the norms of the time of pedagogical work of the teaching staff, The political network electronic scientific journal of the Kuban State Agrarian University, 119, (2016), 1180-1199. 